\title{
Aktivitas Metakognisi Mahasiswa dalam Pemecahan Masalah Program Linear (Studi Kasus Berdasarkan Perbedaan Gender)
}

\author{
Dwiani Listya Kartika \\ Universitas Nahdlatul Ulama (UNU) Purwokerto \\ dl.kartika@unupurwokerto.ac.id
}

\begin{abstract}
ABSTRAK
Tujuan dari penelitian ini adalah untuk mendeskripsikan aktivitas metakognisi mahasiswa dalam pemecahan masalah program linear berdasarkan perbedaan gender. Jenis penelitian ini adalah deskriptif kualitatif dengan subjek penelitian dua orang mahasiswa matematika UNU Purwokerto angkatan 2018 yang terdiri dari satu mahasiswa perempuan dan satu mahasiswa laki-laki yang dipilih berdasarkan kriteria tertentu. Data dikumpulkan dengan menggunakan teknik wawancara berbasis tugas. Hasil penelitian menunjukkan bahwa aktivitas metakognisi yang dialami kedua subjek penelitian meliputi metacognitive awareness, metacognitive regulation, dan metacognitive evaluation. Aktivitas metakognisi yang dilakukan baik subjek laki-laki maupun perempuan dalam penelitian ini menunjukkan hasil yang hampir sama. Perbedaan yang muncul adalah ketika subjek laki-laki merasa kesulitan dan belum mampu untuk mengungkapkan pengetahuan relevan yang diketahui sebelumnya dan terkait dengan permasalahan tetapi subjek mampu memecahkan masalah yang diberikan dengan benar. Sedangkan subjek perempuan mampu mengungkapkan pengetahuan relevan yang diketahui sebelumnya dan terkait dengan permasalahan serta mampu memecahkan masalah yang diberikan dengan benar.
\end{abstract}

Kata kunci: metakognisi, aktivitas metakognisi, pemecahan masalah, program linear, gender.

\section{ABSTRACT}

The purpose of this research was to describe students' metacognition activities in solving linear programming problems based on gender differences. The type of this research is qualitative descriptive with the research subjects of two mathematics students at UNU Purwokerto class 2018 consisting of one female student and one male student selected based on certain criteria. Data were collected using tasks based interview technique. The results showed that the metacognition activities experienced by the two subjects included metacognitive awareness, metacognitive regulation, and metacognitive evaluation. Metacognition activities carried out by both male and female subjects in this research showed almost the same results. The difference that arises is when the male subject finds it difficult and has not been able to express relevant knowledge that is previously known and related to the problem but the subject is able to solve the given problem correctly. This is different from the female subject who is able to reveal relevant knowledge that is known beforehand and is related to the problem and is able to solve the given problem correctly.

Keywords: metacognition, metacognition activites, problem solving, linear programming, gender. 


\section{PENDAHULUAN}

Memecahkan suatu masalah dapat dikatakan sebagai aktivitas dasar manusia. Dalam pembelajaran matematika, pemecahan masalah memiliki peranan yang penting (Novotna et al, 2014; Giganti, 2007; NCTM, 2000). Suherman (2003: 89) menyatakan pemecahan masalah merupakan bagian dari kurikulum matematika yang sangat penting karena dalam proses pembelajaran, siswa dimungkinkan memperoleh pengalaman menggunakan pengetahuan serta keterampilan yang sudah dimiliki untuk diterapkan pada pemecahan masalah yang bersifat tidak rutin. Lebih lanjut, keberhasilan siswa dalam memecahkan masalah matematika juga dipengaruhi oleh berbagai faktor diantaranya adalah motivasi, latar belakang matematika, pengalaman awal, konsentrasi, pendapat tentang matematika, penghargaan terhadap diri sendiri, rasa percaya diri, dan struktur masalah (Guven \& Cabakcor, 2013; Mohd \& Mahmood, 2011; Siswono, 2008). Faktor lain yang juga berpengaruh terhadap keberhasilan siswa dalam proses memecahkan masalah matematika adalah metakognisi (Panaoura et al, 2009; Aurah et al, 2011). Hal ini diperkuat oleh hasil penelitian McLoughlin dan Hollingworth (2003) yang menunjukkan bahwa pemecahan masalah yang efektif dapat diperoleh dengan memberi kesempatan kepada siswa untuk menerapkan strategi metakognisinya ketika menyelesaikan suatu permasalahan matematika.

Metakognisi adalah suatu kata yang berkaitan dengan apa yang dia ketahui tentang dirinya sebagai individu yang belajar dan bagaimana dia mengontrol serta menyesuaikan perilakunya (Suherman, 2001: 95). Meskipun memiliki pengertian yang berbeda, tetapi secara umum metakognisi merupakan kesadaran atau pengetahuan seseorang terhadap proses dan hasil berpikirnya (kognisinya) serta kemampuannya dalam mengontrol dan mengevaluasi proses kognisi tersebut. Metakognisi membantu pemecah masalah untuk mengakui adanya masalah yang perlu diselesaikan, untuk membedakan apa sebenarnya masalahnya, dan untuk memahami bagaimana mencapai tujuan atau solusi dari masalah matematika yang disajikan (Kuzle, 2013).

Siswa yang terampil di dalam metakognisi, akan pandai untuk mengukur diri sehingga ketika mereka sadar akan kemampuannya, mereka akan melakukan pikiran secara strategis lebih baik daripada mereka yang tidak acuh pada pada kerja sistem mental mereka sendiri (Panaoura et al, 2005). Hal ini didukung oleh hasil penelitian Shanon (2008) yang menyatakan bahwa sebagian besar siswa pada awalnya tidak memiliki pemikiran mengenai bagaimana mereka belajar dan gaya belajar apa yang mereka miliki. Namun, setelah diperkenalkan dengan pembelajaran menggunakan strategi metakognisi, mereka tertarik untuk mencoba melakukan survei tentang gaya belajar mereka sendiri dengan berpikir mengenai hasil proses berpikirnya.

Selanjutnya, dalam hubungannya dengan pembelajaran matematika, pemanfaatan metakognisi dapat dilihat ketika siswa diminta untuk mengkomunikasikan gagasan-gagasan matematika yang dimiliki atau berdiskusi dalam kelompok. Aktivitas metakognisi akan terjadi jika ada interaksi antara beberapa individu yang membicarakan suatu masalah. Oleh karena itu, aktivitas metakognisi siswa dalam proses pembelajaran matematika memiliki potensi untuk dapat dikembangkan dengan baik ketika siswa memecahkan masalah saat mempelajari suatu materi matematika.

Beberapa tahun terakhir, penelitian mengenai aktivitas metakognisi mulai banyak melihat apakah terdapat perbedaan di antara siswa laki-laki dan perempuan dalam hal kesadaran metakognitifnya. Namun, penelitian-penelitian tersebut menunjukkan berbagai hasil yang tidak 
konsisten. Hasil penelitian Nurmaliah (2008) menemukan bahwa siswa perempuan memiliki keterampilan metakognisi lebih tinggi dari siswa laki-laki. Kolic-Vehovec dan Bajsanski (2006) juga menyatakan bahwa siswa perempuan menggunakan strategi metakognitif yang lebih banyak dibandingkan dengan siswa laki-laki. Sejalan dengan hal tersebut, penelitian Liliana dan Lavinia (2011) juga menunjukkan adanya perbedaan kesadaran metakognisi ada laki-laki dan perempuan. Di sisi lain, Abu-Snoubar (2017) menemukan bahwa tidak terdapat perbedaan yang signifikan antara siswa laki-laki dan perempuan dalam hal strategi metakognitifnya. Penelitian lain (Misu \& Masi, 2017) juga menunjukkan bahwa tidak ada perbedaan signifikan antara mahasiswa laki-laki dan perempuan dalam kesadaran metakognitif pada matematika. Hasil yang tidak konsisten ini menunjukkan bahwa peran gender dalam aktivitas metakognisi masih butuh ditelaah lebih dalam.

Fenomena menarik ditemui peneliti ketika memberikan pembelajaran matematika pada mata kuliah Program Linear khususnya ketika memecahkan masalah yang berhubungan dengan metode simpleks. Dari hasil pengamatan peneliti selama satu semester, terdapat dua mahasiswa yang terdiri dari satu mahasiswa perempuan dan satu mahasiswa laki-laki yang memiliki gejala selalu memikirkan kembali apa yang telah dipikirkannya. Proses berpikir kembali tentang apa yang telah dipikirkannya tersebut berkaitan erat dengan aktivitas metakognisi. Lebih lanjut, Program Linear (Linear Programming) merupakan matematika terapan dari aljabar linear yang banyak digunakan dalam bidang industri, transportasi, perdagangan, perkebunan, dan sebagainya.

Salah satu metode yang digunakan untuk memecahkan masalah Program Linear adalah metode simpleks. Metode simpleks merupakan metode yang biasanya digunakan untuk memecahkan permasalahan pemrograman linear yang kombinasi variabelnya terdiri dari tiga variabel atau lebih. Metode penyelesaian dari metode simpleks dilakukan melalui proses perhitungan yang berulang-ulang (iteration). Dalam proses perhitungan tersebut, langkah perhitungan yang sama akan diulang-ulang sampai solusi optimal diperoleh sehingga dibutuhkan ketelitian dan ketekunan yang tinggi dalam memecahkan masalah tersebut dari awal hingga akhir perhitungan agar diperoleh solusi optimal yang benar. Apabila pemecah masalah melakukan kesalahan di awal perhitungan, maka sangat besar kemungkinan solusi akhir yang diperoleh tidak sesuai dengan permasalahan yang disajikan. Berdasarkan pemaparan tersebut, peneliti tertarik ingin mengetahui tentang aktivitas metakognisi pada mahasiswa saat memecahkan masalah program linear khususnya pada permasalahan yang berhubungan dengan perhitungan metode simpleks berdasarkan perbedaan gender.

\section{METODE}

Penelitian ini dilaksanakan pada semester genap tahun akademik 2019/2020. Subjek penelitian yang diambil adalah dua orang mahasiswa matematika UNU Purwokerto angkatan 2018 yang terdiri dari satu mahasiswa perempuan dan satu mahasiswa laki-laki. Subjek ini dipilih karena beberapa pertimbangan yaitu: (1) mahasiswa angkatan 2018 sudah mendapatkan mata kuliah Pemrograman Linear, sehingga diharapkan dapat menyelesaikan permasalahan tentang masalah Program Linear khususnya yang berhubungan dengan perhitungan metode simpleks; (2) subjek yang dipilih adalah subjek yang berdasarkan hasil pengamatan peneliti selama satu semester, memiliki gejala selalu memikirkan kembali apa yang telah dipikirkannya, 
mampu memecahkan permasalahan yang diberikan dengan benar dan dengan mempertimbangkan kemampuan subjek dalam berkomunikasi agar pengungkapan aktivitas metakognisi dapat berlangsung dengan baik, (3) pengelompokan subjek didasarkan pada perbedaan gender yaitu laki-laki dan perempuan. Hasil yang diperoleh dari penelitian ini berupa deskripsi tentang aktivitas metakognisi mahasiswa dalam pemecahan masalah program linear sehingga penelitian ini termasuk dalam jenis penelitian deskriptif kualitatif.

Pengumpulan data dalam penelitian ini dilakukan dengan teknik wawancara berbasis tugas, yaitu subjek diberi lembar tugas tertulis tentang permasalahan program linear khususnya tentang perhitungan metode simpleks. Tugas tertulis terdiri dari dua soal pemecahan masalah. Pada saat memecahkan soal tersebut, subjek diminta untuk mengomunikasikan gagasan atau ide tentang apa yang dipikirkannya. Kemudian untuk setiap tahapan dalam aktivitas metakognisi yang akan dikaji diadakan wawancara mendalam untuk mengetahui aktivitas metakognisi yang dilakukan.

Data yang diperoleh pada saat wawancara disusun dalam sebuah transkrip wawancara untuk selanjutnya dilakukan analisis terkait dengan aktivitas metakognisi yang dilakukan. Analisis data aktivitas metakognisi subjek penelitian tersebut didasarkan pada masing-masing indikator awareness, evaluation, dan regulation. Deskripsi dan indikator dari masing-masing aktivitas metakognisi tersebut dapat dilihat pada Tabel 1 yang diadaptasi dari hasil penelitian Magiera dan Zawojewski (2011).

Tabel 1. Deskripsi dan Indikator Aktivitas Metakognisi

\begin{tabular}{ll}
\hline \multicolumn{1}{c}{ Jenis } & \multicolumn{1}{c}{ Indikator Aktivitas Metakognisi } \\
\hline Metacognitive & Ungkapan tentang cara berpikir matematika diri sendiri atau orang lain, \\
meliputi: & 1. hal-hal yang saya/orang lain ketahui tentang suatu permasalahan; \\
& 2. pengetahuan relevan yang diketahui terkait dengan tugas; \\
& 3. hal yang telah dilakukan di lain waktu yang dapat membantu \\
& menyelesaikan masalah; \\
4. mengetahui posisi dirinya dalam proses pemecahan masalah. & Pendapat tentang cara berpikir matematika diri sendiri/orang lain, \\
Metacognitive & meliputi: \\
regulation & 1. merencanakan strategi; \\
2. langkah-langkah kerja dalam menyelesaikan & masalah; \\
3. memikirkan tentang apa yang dilakukan selanjutnya; & 4. memilih strategi pemecahan masalah yang akan digunakan. \\
Penilaian yang dibuat berdasarkan cara berpikir matematika diri & sendiri/orang lain, meliputi: \\
1. penilaian terhadap keterbatasan proses berpikir diri & sendiri atau orang lain; \\
evaluation & 2. efektifitas dari strategi yang dipilih; \\
3. penilaian terhadap hasil yang diperoleh; & 4. penilaian terhadap kesulitan yang dihadapi; \\
5. penilaian terhadap perkembangan kemampuan dan pemahaman diri & sendiri.
\end{tabular}




\section{HASIL DAN PEMBAHASAN}

Berikut ini adalah hasil penelitian dan pembahasan aktivitas metakognisi yang dilakukan oleh kedua subjek saat memecahkan masalah program linear yang disajikan. Untuk selanjutnya subjek perempuan disebut dengan subjek NA dan subjek laki-laki disebut dengan subjek DN kemudian masalah 1 disebut dengan M1 dan masalah 2 disebut dengan M2.

Subjek NA mulai memecahkan M1 dengan membaca dan memahami soal. Pada tahap awal, subjek dapat mengidentifikasi informasi yang diberikan dalam permasalahan yang meliputi informasi yang diketahui dan ditanyakan dalam bentuk yang lebih operasional, dalam hal ini subjek dapat mengubah bentuk fungsi tujuan dan fungsi pembatas yang disajikan dalam bentuk baku metode simpleks. Hal ini terlihat dari cuplikan jawaban subjek pada Gambar 1.

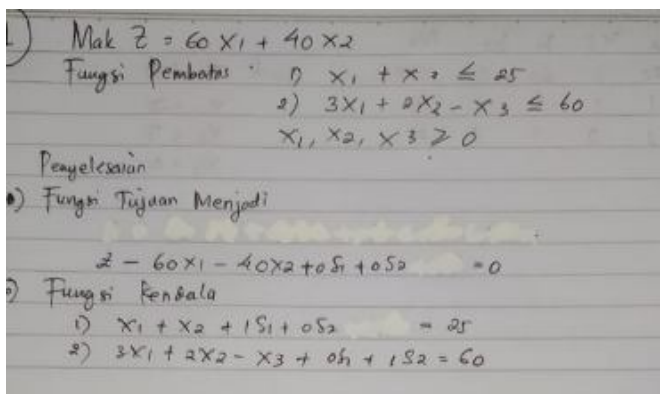

Gambar 1. Pekerjaan Awal Subjek NA

Selanjutnya pada saat dilakukan konfirmasi melalui wawancara mengenai materi yang relevan digunakan untuk memecahkan masalah, subjek mampu menjawabnya sesuai dengan pengetahuan yg dimiliki meskipun pada awalnya subjek merasa kesulitan untuk mengingat kembali materi sebelumnya yang telah dipelajari. Selain itu, subjek merasa mampu menyelesaikan permasalahan tersebut setelah membaca dan memahami soal, aserta mampu memperkirakan waktu yang dibutuhkan untuk menyelesaikan permasalahan tersebut karena waktu perkiraan dan waktu penyelesaian ternyata sama dengan yang diungkapkan subjek sesaat sebelum mulai mengerjakan soal yaitu 30 menit. Hal ini menunjukkan subjek DN melakukan aktivitas metacoginitve awareness.

Kemudian pada tahap selanjutnya, setelah subjek selesai mengerjakan soal, peneliti melakukan konfirmasi melalui wawancara. Dari hasil wawancara, subjek mampu menyebutkan langkah-langkah penyelesaian yang digunakan dan merasa yakin bahwa langkah-langkahnya sudah benar. Namun, subjek merasa ragu-ragu dengan jawaban akhir atau kesimpulan yang diambil (Gambar 2) karena Z pada tabel simpleks sudah menunjukkan positif semua tetapi di kolom variabel fungsi pembatasnya tidak menunjukkan matriks identitas sehingga merasa perlu untuk merevisi jawaban akhir.

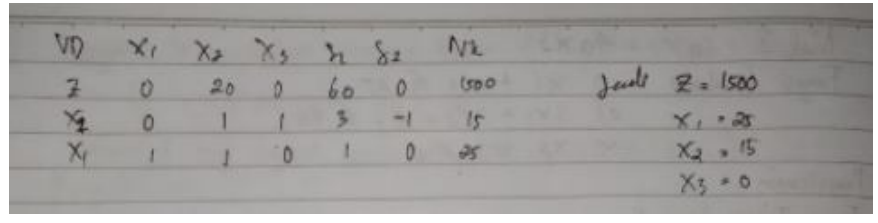

Gambar 2. Jawaban Awal Kesimpulan Akhir 
Subjek NA memikirkan kembali setelah merasa ragu-ragu dengan kesimpulan akhir lalu memeriksa kembali jawabannya dan kemudian menyadari telah melakukan kesalahan di bagian kesimpulan sehingga mengganti jawaban akhirnya yaitu dengan menukar nilai $\mathrm{x}_{2}$ dan $\mathrm{x}_{3}$ yaitu $\mathrm{x}_{2}=0$ dan $\mathrm{x}_{3}=15$. Ini menunjukkan subjek melakukan aktivitas metacognitive regulation karena subjek menyadari proses berpikirnya dengan mampu menjelaskan langkah-langkah yang digunakan untuk memecahkan masalah.

Setelah melalui serangkaian wawancara berupa pertanyaan metakognisi yang diberikan, subjek NA melakukan evaluasi terhadap hasil pekerjaan tertulis yang telah diselesaikan. Subjek NA menilai bahwa hasil pekerjaannya sudah benar dan sudah sesuai dengan tuntutan permasalahan. Subjek juga menjelaskan efektivitas strategi yang dipilih dan memberikan contoh pada permasalahan lain yang sejenis.

Hasil ini menunjukkan pada saat proses pemecahan masalah M1 subjek NA melakukan aktivitas metacognitive evaluation yaitu menyadari proses berpikirnya dengan menilai dan meyakini hasil yang diperoleh sudah benar. Selain itu, subjek NA juga dapat mengidentifikasi strategi yang digunakan selanjutnya untuk permasalahan lain yang sejenis secara garis besar tetapi belum mampu menyebutkan alternatif lain dalam memecahkan M1 secara lebih efektif.

Kemudian hasil analisis wawancara dan pekerjaan tertulis subjek NA ketika memecahkan M2 menunjukkan hasil yang hampir sama dengan ketika memecahkan M1. Oleh karena itu, aktivitas metacognitive awareness subjek NA yang dilakukan adalah subjek menyadari proses berpikirnya dengan mengidentifikasi informasi yang diberikan dalam permasalahan yang meliputi informasi yang diketahui dan ditanyakan dalam bentuk yang lebih operasional, dalam hal ini subjek dapat mengubah bentuk fungsi tujuan dan fungsi pembatas yang disajikan dalam bentuk baku metode simpleks dan mampu menjelaskan kembali apa yang dituliskan dengan kalimat sendiri. Selanjutnya ketika menggali pengetahuan sebelumnya yang relevan dengan permasalahan, subjek NA mampu menyebutkan pengetahuan awal sebagai materi prasayarat yang dibutuhkan dan menyebutkan alasan penggunaan pengetahuan awal tersebut. Kemudian, subjek NA mampu membuat prediksi waktu yang dibutuhkan serta merasa yakin mampu menyelesaikan M2 sesuai perkiraan waktu yang dibuat.

Selanjutnya, subjek menyadari proses berpikirnya dengan menyebutkan rencana solusi yang akan dilakukan yaitu dengan menyebutkan hal yang akan pertama kali dilakukan dan konsep yang akan digunakan dalam pemecahan masalah. Subjek juga mampu menjelaskan langkah yang digunakan dalam memecahkan masalah untuk mengidentifikasi strategi yang digunakan dan melakukan verifikasi jawaban tertulisnya yang dianggap belum benar. Hal ini menunjukkan subjek mengalami aktivitas metacognitive regulation.

Subjek memikirkan kembali untuk melakukan perbaikan jawaban setelah melakukan verifikasi dan klarifikasi melalui proses wawancara yang dilakukan dan melakukan evaluasi terhadap hasil pekerjaan tertulis yang telah diselesaikan. Subjek NA menilai hasil penyelesaiannya belum benar meskipun subjek merasa langkah yang digunakan sudah benar dan sesuai dengan permasalahan, sehingga subjek berinisiatif untuk memperbaiki jawaban dan melakukan pengecekan ulang jawaban dari awal. Subjek NA menyadari kesalahan perhitungan indeks di tabel awal sehingga menyebabkan kesalahan perhitungan sampai di akhir kesimpulan yang ditunjukkan pada Gambar 3. Kemudian subjek memperbaiki jawaban akhir sehingga diperoleh hasil seperti pada Gambar 4. Hal ini terlihat dari cuplikan hasil pekerjaan tertulis subjek NA sebagai berikut. 


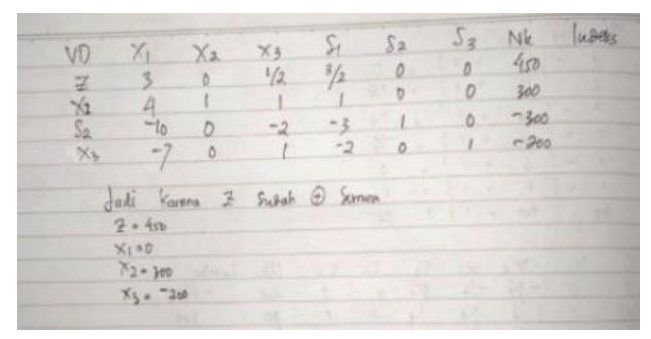

Gambar 3. Pekerjaan Awal Subjek Bagian Kesimpulan

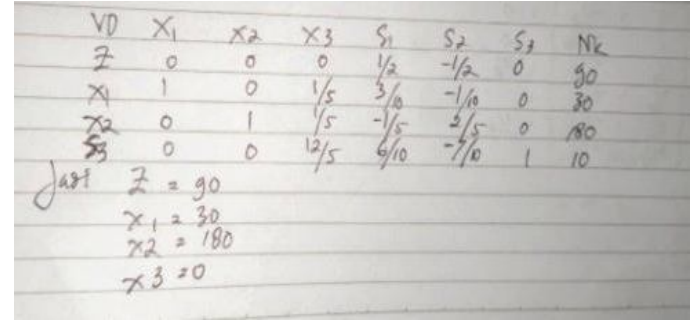

Gambar 4. Pekerjaan Akhir Subjek Bagian Kesimpulan

Hasil ini menunjukkan pada saat proses pemecahan masalah M2 subjek NA melakukan aktivitas metacognitive evaluation yaitu menyadari proses berpikirnya dengan menilai dan meyakini hasil yang diperoleh sudah benar. Subjek NA juga dapat menyebutkan efektifitas strategi yang dipilih dan melakukan evaluasi tentang kesulitan yang dihadapi. Selain itu, subjek NA juga dapat mengidentifikasi strategi yang digunakan selanjutnya untuk permasalahan lain yang sejenis secara garis besar tetapi belum mampu menyebutkan alternatif lain dalam memecahkan M2 secara lebih efektif. Hal ini terlihat dari cuplikan hasil wawancara berikut.

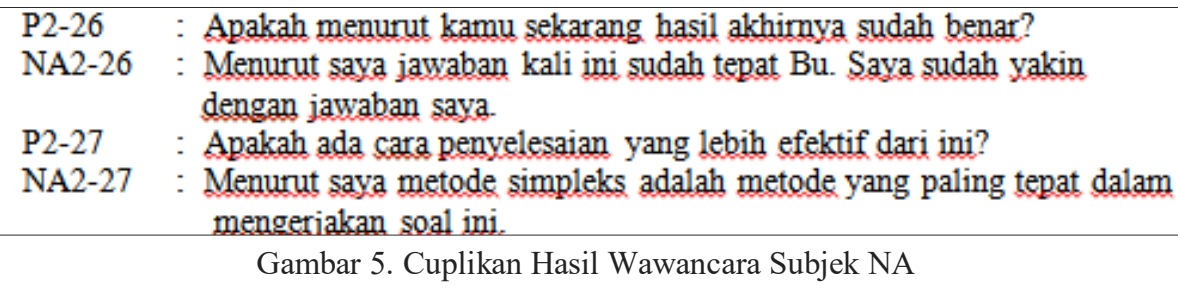

Selanjutnya, hasil analisis wawancara dan pekerjaan tertulis subjek laki-laki atau subjek DN yaitu dimulai ketika subjek memecahkan masalah dengan membaca dan memahami soal. Pada tahap awal, subjek dapat mengidentifikasi informasi yang diberikan dalam permasalahan yang meliputi informasi yang diketahui dan ditanyakan dalam bentuk yang lebih operasional, dalam hal ini subjek dapat mengubah bentuk fungsi tujuan dan fungsi pembatas yang disajikan dalam bentuk baku metode simpleks. Hal ini terlihat dari cuplikan jawaban pada Gambar 6 .

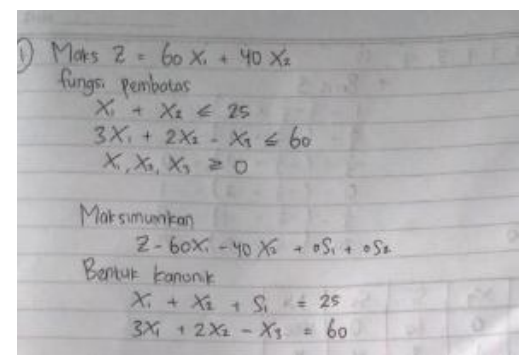

Gambar 6. Pekerjaan Awal Subjek DN

Kemudian pada saat dilakukan konfirmasi melalui wawancara mengenai materi sebelumnya yang relevan digunakan untuk memecahkan masalah, subjek merasa kesulitan untuk menjawabnya meskipun sudah diberikan serangkaian pertanyaan metakognisi. Namun, subjek merasa mampu menyelesaikan permasalahan tersebut setelah membaca dan memahami soal, serta mampu memperkirakan waktu yang dibutuhkan untuk menyelesaikan permasalahan tersebut karena waktu perkiraan dan waktu penyelesaian ternyata sama dengan yang 
diungkapkan subjek sesaat sebelum mulai mengerjakan soal yaitu 30 menit. Hal ini menunjukkan subjek DN melakukan aktivitas metacoginitve awareness.

Pada tahap selanjutnya, setelah subjek selesai mengerjakan soal, peneliti melakukan konfirmasi pekerjaan tertulis subjek melalui wawancara. Dari hasil wawancara, subjek mampu menyebutkan langkah-langkah penyelesaian yang digunakan dan merasa yakin bahwa langkahlangkahnya sudah benar. Hal ini terlihat dari cuplikan wawancara berikut.

\begin{tabular}{|c|c|}
\hline P1-11 & $\begin{array}{l}\text { : Langkah-langkah apa saja yang tadi kamu lakukan untuk mengerjakan } \\
\text { soal? }\end{array}$ \\
\hline DN1-11 & $\begin{array}{l}\text { Jadi langkah-langkah untuk mengeriakan fungsi maksimum } Z \text { yaitu yang } \\
\text { pertama kita jadikan fungsi } Z \text { nya minus semua. Pindah ke ruas kiri. } \\
\text { Jadi minus semua. Lalu yang fungsi pembatasnya itu ditambahin S1 } \\
\text { dan S2. Setelah itu kita bikin tabel untuk mencari angka kunci dengan } \\
\text { rumusnya baris indeks terkecil sama kolom negatif terbesar. Setelah } \\
\text { kita mengetahui angka kunci. kita jadikan angka kunci itu nilainya } \\
\text { satu. Semisal } 3 \text { dijadikan satu berarti tiga dibagi } 3 \text { sampai semua } \\
\text { barisnya sama dibagi } 3 \text { semua. Lalu untuk mencari nilai baris satu dan } \\
\text { baris dua rumusnya baris dikurangi dengan baris yang ada angka } \\
\text { kuncinya dikali dengan transformasi baris. Setelah kita keriakan } \\
\text { semuanya diperoleh hasilnya sampai } Z \text { nya tu tidak negatif. Kalau Z } \\
\text { nya sudah tidak ada yang negatif berarti kita sudah mengetahui } \\
\text { hasilnya. }\end{array}$ \\
\hline $\mathrm{P} 1-12$ & $\begin{array}{l}\text { : Menurut kamu langkah-langkah yang kamu lakukan sudah benar atau } \\
\text { belum? }\end{array}$ \\
\hline DN1-12 & : Menurut saya sudah $\mathrm{Bu}$ \\
\hline
\end{tabular}

Gambar 7. Cuplikan Hasil Wawancara Subjek DN

Berdasarkan pemaparan tersebut, subjek melakukan aktivitas metacognitive regulation karena subjek menyadari proses berpikirnya dengan mampu menjelaskan langkah-langkah yang digunakan untuk memecahkan masalah.

Kemudian subjek DN melakukan aktivitas metacognitive evaluation dengan melakukan evaluasi terhadap hasil pekerjaan tertulis yang telah diselesaikan. Namun, subjek belum bisa menjelaskan efektivitas strategi yang dipilih dan memberikan contoh pada permasalahan lain yang sejenis. Subjek DN menilai bahwa hasil pekerjaannya sudah benar dan sudah sesuai dengan tuntutan permasalahan. Hal ini terlihat dari cuplikan wawancara berikut.

\begin{tabular}{|ll|}
\hline P1-16 & : Apakah langkah-langkah yang kamu lakukan sudah sesuai dengan \\
& permasalahan? Apakah sesuai degan harapan kamu? \\
DN1-16 & : Menurut saya hasilnya sudah sesuai harapan saya Bu. Karena nilai $\mathrm{Z}$ \\
& akhirnya sudah tidak ada yang negatif \\
P1-17 & : Menurut kamu hasil akhirnya sudah benar atau belum? \\
DN1-17 & Menurut saya hasil akhirnya sudah benar. Saya kerjakan hasil akhirnya \\
& $\begin{array}{l}\text { Z maksnya = } 1500, x 1 \text { nya } 25, \mathrm{x} 2 \text { nya nol, } \mathrm{x} 3 \text { nya } 15 . \text { Bisa dibuktikan } \\
\text { dengan memasukkan nilai nya ke fungsi pembatasnya. }\end{array}$
\end{tabular}

Gambar 8. Cuplikan Hasil Wawancara Subjek DN

Selanjutnya, hasil analisis wawancara dan pekerjaan tertulis subjek DN ketika memecahkan M2 menunjukkan hasil yang hampir sama dengan ketika memecahkan M1. Oleh karena itu, aktivitas metacognitive awareness subjek DN yang dilakukan adalah subjek menyadari proses berpikirnya dengan mengidentifikasi informasi yang diberikan dalam permasalahan yang meliputi informasi yang diketahui dan ditanyakan dalam bentuk yang lebih operasional, dalam hal ini subjek dapat mengubah bentuk fungsi tujuan dan fungsi pembatas yang disajikan dalam bentuk baku metode simpleks dan mampu menjelaskan kembali apa yang 
dituliskan dengan kalimat sendiri. Selanjutnya ketika menggali pengetahuan sebelumnya yang sesuai dengan permasalahan, subjek DN belum mampu memberikan jawaban yang relevan sama halnya pada saat memecahkan M1. Subjek justru menjelaskan langkah penyelesaian yang digunakan. Hal ini terlihat dari cuplikan wawancara berikut.

\begin{tabular}{|cc|}
\hline P2-05 & : Untuk menyelesaikan permasalahan ini pengetahuan awal atau materi \\
& prasyarat apa yang kamu gunakan? \\
DN2-05 & : Untuk mengerjakan soal ini seperti biasa ya, maks Z nya dipindah ke ruas \\
& kiri jadi minus semua dan yang fungsi pembatasnya ditambahkan S. S \\
& itu Slack, karena fungsi pembatasnya ada 3 berarti S nya ada 3 yaitu \\
& S1. S2. dan S3.
\end{tabular}

Gambar 9. Cuplikan Hasil Wawancara Subjek DN

Kemudian, subjek DN mampu membuat prediksi waktu yang dibutuhkan serta merasa yakin mampu menyelesaikan M2 sesuai perkiraan waktu yang dibuat. Selanjutnya, subjek menyadari proses berpikirnya dengan menyebutkan rencana solusi yang akan dilakukan yaitu dengan menyebutkan hal yang akan pertama kali dilakukan. Subjek juga mampu menjelaskan langkah yang digunakan dalam memecahkan masalah untuk mengidentifikasi strategi yang digunakan dan melakukan verifikasi jawaban tertulisnya yang dianggap belum benar. Hal ini menunjukkan subjek mengalami aktivitas metacognitive regulation.

Subjek merasa belum yakin dengan perhitungan yang dilakukan ketika menghitung angka kunci di tabel kedua meskipun langkah-langkah yang dilakukan sudah benar sehingga memikirkan kembali untuk melakukan perbaikan jawaban setelah melakukan verifikasi dan klarifikasi melalui proses wawancara yang dilakukan. Hal ini terlihat dari cuplikan hasil wawancara berikut.

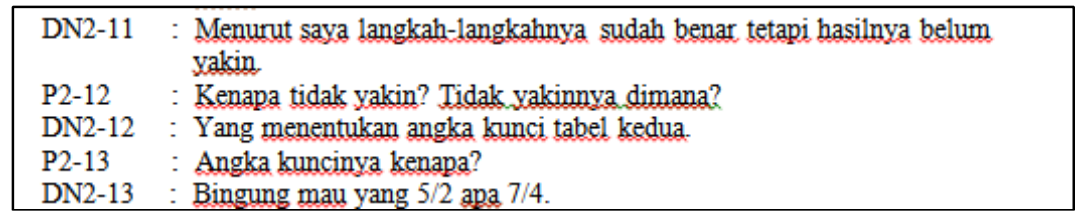

Gambar 10. Cuplikan Hasil Wawancara Subjek DN

Setelah diberi serangkaian pertanyaan metakognisi, subjek akhirnya meyakini jawaban yang diberikan sudah benar. Hasil ini menunjukkan pada saat proses pemecahan masalah M2 subjek DN melakukan aktivitas metacognitive evaluation yaitu menyadari proses berpikirnya dengan menilai dan meyakini hasil yang diperoleh sudah benar. Subjek DN belum dapat menyebutkan efektifitas strategi yang dipilih dan belum mampu menyebutkan alternatif lain dalam memecahkan M1 secara lebih efektif. Hal ini terlihat dari hasil wawancara berikut.

\begin{tabular}{|ll|}
\hline P2-17 & : Ladi jawabannya sudah sesuai harapan kamu? Sudah sesuai dengan \\
& tuntutan permasalahan? Atau masih belum yakin? \\
DN2-17 & : Sudah Bu, sudah yakin. \\
P2-18 & : Kenapa sudah yakin kalau sekarang? \\
DN2-18 & : Karena sudah dibuktikan hasil akhinya. \\
P2-19 & : Apakah menurut kamu sekarang hasil akhirnya sudah benar? \\
DN2-19 & : Sudah Bu. \\
P2-20 & : Apakah ada cara penyelesaian yang lebih efektif dari ini? \\
DN2-20 & : Kemungkinan ada Bu, tetapi saya belum tahu. \\
\hline
\end{tabular}

Gambar 11. Cuplikan Hasil Wawancara Subjek DN 
Berdasarkan pemaparan hasil penelitian di atas, seluruh subjek penelitian baik subjek perempuan maupun laki-laki melakukan aktivitas metacognitive awareness, metacognitive regulation, dan metacognitive evaluation. Subjek perempuan menyadari proses berpikirnya dengan melakukan aktivitas metacognitive awareness yaitu ketika subjek mampu mengungkapkan hal-hal yang diketahui tentang permasalahan program linear yang disajikan. Subjek juga mampu mengungkapkan pengetahuan relevan yang diketahui sebelumnya dan terkait dengan permasalahan serta membuat prediksi tentang rencana solusi yang akan digunakan untuk memecahkan permasalahan. Ini diperkuat oleh Maulidyawati (2015) yang menyatakan bahwa mengetahui pengetahuan relevan yang terkait dengan masalah merupakan metacognitive awareness.

Di sisi lain, subjek laki-laki pada penelitian ini merasa kesulitan dan belum mampu mengungkapkan pengetahuan relevan yang diketahui sebelumnya dan terkait dengan permasalahan meskipun sudah diberi serangkaian pertanyaan metakognisi. Kemampuan untuk mengetahui pengetahuan yang relevan dan berhubungan dengan permasalahan berhubungan erat dengan aktivitas belajar yang dilakukan sebelumnya dan bahan belajar yang mereka miliki. Lebih lanjut, Nurmaliah (2008) menyatakan bahwa siswa perempuan lebih mampu dalam berpikir kritis dan mengatur cara berpikirnya sehingga hasil belajar juga akan lebih tinggi. Selain itu, siswa perempuan biasanya menggunakan strategi belajar yang lebih banyak dibandingkan dengan laki-laki. Perbedaan karakteristik ini dapat berpengaruh terhadap kemampuan skimming mereka. Hal ini juga dapat dikaitkan dengan hasil penelitian Veloo et al. (2014) mengenai kesadaran metakognitif pada mahasiswa yang menyimpulkan bahwa mahasiswa perempuan cenderung lebih sering menggunakan strategi metakognitif dalam membaca bacaan akademik. Selain itu, penelitian Logan dan Johnston (2009) menyimpulkan bahwa siswa perempuan memiliki kemampuan pemahaman bacaan yang lebih baik dibandingkan dengan siswa laki-laki.

Meskipun demikian, subjek laki-laki menyadari proses berpikirnya dengan melakukan aktivitas metacognitive awareness ketika subjek mampu mengungkapkan hal-hal yang diketahui tentang permasalahan program linear yang disajikan dan membuat prediksi tentang rencana solusi yang akan digunakan untuk memecahkan permasalahan. Hal ini sejalan dengan Joseph (2010) yang menyatakan bahwa metacognitive awareness merupakan kemampuan untuk merefleksikan pemikiriannya sendiri dan mengembangkannya dalam belajar atau memecahkan masalah. Selain itu, menurut Schraw dan Dennison (1994) metacognitive awareness memungkinkan siswa untuk merencanakan, mengurutkan, dan memonitor cara belajarnya untuk meningkatkan kinerjanya.

Selanjutnya, subjek perempuan dan laki-laki menyadari proses berpikirnya dengan melakukan aktivitas metacognitive regulation ketika subjek mampu mengungkapkan langkahlangkah yang digunakan dalam pemecahan masalah dan mengembangkannya serta melakukan verifikasi dan klarifikasi penyelesaian awal dengan penyelesaian yang lebih akurat. Menurut Jacobse dan Harskamp (2012) metacognitive regulation merujuk pada aktivitas mental yang digunakan untuk mengatur strategi kognitif dalam memecahkan masalah. Salah satu contohnya adalah ketika siswa mengubah cara yang digunakan untuk memecahkan masalah, keputusan untuk melakukan hal tersebut merupakan metacognitive regulation sedangkan ketika ia menuliskannya dalam lembar kerja merupakan aktivitas kognitif. Dalam penelitian ini, baik subjek laki-laki maupun perempuan melakukan aktivitas metacognitive regulation ketika 
subjek memutuskan untuk memikirkan kembali langkah yang digunakan secara berulang-ulang sebelum menyimpulkan tentang apa yang dipikirkannya. Hal ini sejalan dengan Purnomo et al (2016) yangmenyatakan bahwa memeriksa jawaban secara berulang-ulang sebelum membuat suatu kesimpulan merupakan salah satu karakteristik dari metacognitive regulation.

Kemudian, ketika mengalami aktivitas metacognitive evaluation baik subjek laki-laki maupun perempuan melakukan penilaian terhadap hasil pemecahan masalah dan meyakini bahwa jawabannya benar setelah melakukan pengecekan berulang-ulang. Hal ini memperkuat hasil penelitian Magiera dan Zawojewski (2011) yang menunjukkan bahwa melakukan pengecekan secara berulang-ulang sebelum menilai apa yang dipikirkannya merupakan metacognitive evaluation. Selanjutnya, salah satu indikator aktivitas metacognitive evaluation menurut Magiera dan Zawojewski (2011) adalah menilai efektivitas strategi yang digunakan. Dalam penelitian ini, kedua subjek hanya menyatakan bahwa metode simpleks efektif untuk memecahkan permasalahan program linear yang disajikan tetapi belum mampu membandingkan dengan metode yang lain karena keterbatasan wawasan.

\section{SIMPULAN}

Subjek laki-laki dan perempuan yang menjadi subjek penelitian ini mengalami aktivitas metakognisi ketika memecahkan masalah program linear dengan melibatkan metacognitive awareness, metacognitive regulation, dan metacognitive evaluation. Aktivitas metakognisi yang dilakukan baik subjek laki-laki maupun perempuan dalam penelitian ini berdasarkan indikator-indikator yang dirujuk dalam penelitian ini menunjukkan hasil yang hampir sama. Perbedaan yang muncul adalah ketika subjek laki-laki merasa kesulitan dan belum mampu untuk mengungkapkan pengetahuan relevan yang diketahui sebelumnya dan terkait dengan permasalahan tetapi subjek mampu memecahkan masalah yang diberikan dengan benar. Sedangkan subjek perempuan mampu mengungkapkan pengetahuan relevan yang diketahui sebelumnya dan terkait dengan permasalahan serta mampu memecahkan masalah yang diberikan dengan benar.

Hasil penelitian menunjukkan bahwa dengan adanya aktivitas metakognisi tersebut, siswa menjadi lebih sering mengevaluasi apa yang telah dilakukannya dalam proses memecahkan masalah. Oleh karena itu, penting bagi guru untuk melatih siswa dalam menggunakan keterampilan metakognitif pada saat memecahkan masalah matematika. Kemudian, bagi peneliti selanjutnya, perlu diadakan penelitian lebih lanjut mengenai aktivitas metakognisi siswa dalam memecahkan masalah matematika untuk materi lain dan melalui tinjauan yang berbeda serta dengan subjek penelitian yang berada pada tingkat usia yang berbeda pula untuk menjadi salah satu bagian dari referensi pembelajaran matematika.

\section{DAFTAR PUSTAKA}

Abu-Snoubar, T. K. (2017). Gender Differences in Metacognitive Reading Strategy Use among English as a Foreign Language Students at Al-Balqa Applied University. Journal of Education and Practice. 8(18), 1-12. Retrieved from:https://www.iiste.org/ Journals/index.php/JEP/article/view/37655 
Aurah, C., Keaikitse, S., Isaacs, C., \& Fincii, H. (2011). The role of metacognition in everyday problem solving among primary students in Kenya. Probl. Educ, 21, 9-21.

Giganti, P. (2007). Why teach problem solving, part 1: the world needs good problem solvers!. CMC Com-MuniCator, 31(4).

Guven, B., \& Cabakcor, B. O. (2013). Factors influencing mathematical problem-solving achievement of seventh grade Turkish students. Learning and Individual Differences, 23, 131-137.

Jacobse, A. E., \& Harskamp, E. G. (2012). Towards efficient measurement of metacognition in mathematical problem solving. Metacognition and Learning, 7(2), 133-149.

Joseph, N. (2009). Metacognition needed: Teaching middle and high school students to develop strategic learning skills. Preventing School Failure: AlternativeEducation for Children and Youth, 54(2), 99-103.

Kolic-Vehovec, S., Bajsanski, I., \& Zubkovic, B. R. (2010). Metacognition and Reading Comprehension: Age and Gender Differences. In A. Efklides \& P. Misailidi (Eds.). Trends and prospects in metacognition research. (pp. 327-344). New York: Springer.

Kuzle, A. (2013). Patterns of metacognitive behavior during mathematics problem-solving in a dynamic geometry environment. International Electronic Journal of Mathematics Education, 8(1), 20-40.

Liliana, C., \& Lavinia, H. (2011). Gender Differences in Metacognitive Skills. A Study of the 8th Grade Pupils in Romania. Procedia - Social and Behavioral Sciences 29, 396-401. doi: 10.1016/j.sbspro.2011.11.255

Logan, S., \& Johnston, R.S. (2009). Gender differences in reading ability and attitudes: Examining where these differences lie. Journal of Research in Reading, 32(2), 199- 214. doi: $10.1111 / \mathrm{j} .1467-9817.2008 .01389 . x$

Magiera, M. T., \& Zawojewski, J. S. (2011). Characterizations of social-based and self-based contexts associated with students' awareness, evaluation, and regulation of their thinking during smallgroup mathematical modeling. Journal for Research in Mathematics Education, 42(5), 486-520.

Maulidyawati, D., (2015). Proses metakognisi siswa Sekolah Menengah Pertama dalam menyelesaikan soal PISA. (Doctoral Dissertation). Program Pascasarjan UM, Malang.

McLoughlin, C, \& Hollingworth, R. (2003). Exploring a Hidden Dimension of Online Quality: Matacognitive Skill Development. 16th ODLAA BiennialForum Conference Proceedings.

Misu, L. \& Masi, L. (2017). Comparison of Metacognition Awareness of Male and Female Students Based on Mathematics Ability in Department of Mathematics Education of Haluleo University. InternationalmJournal of Education and Research, 5(6), 43-50. Retrieved from:https://www.ijern.com/journal/2020/June-2020/04.pdf.

Mohd, N., \& Mahmood, T. F. P. T. (2011). The effects of attitude towards problem solving in mathematics achievements.

National Council of Teachers of Mathematics (NCTM). (2000). Principles and standards for school mathematics. Reston, VA: NCTM.

Novotna, J., Eisenmann, P., Přibyl, J., Ondrušová, J., \& Břehovský, J. (2014). Problem solving in school mathematics based on heuristic strategies. Journal on Efficiency and Responsibility in Education and Science, 7(1), 1-6. 
Nurmaliah, C. (2008). Analisis Keterampilan Metakognisi Siswa SMP Negeri di Kota Malang Berdasarkan Kemampuan Awal, Tingkat Kelas, dan Jenis Kelamin. Jurnal Unsyiah. Retrieved from http://www.jurnal.unsyiah.ac.id/JBE/article/download/410/580.

Suherman, E. (2001). Strategi Pembelajaran Matematika Kontemporer. Bandung: JICA UPI.

Suherman, E. (2003). Strategi Pembelajaran Matematika Kontemporer, rev.ed.. Bandung: JICA UPI.

Panaoura, A, Christou, C, \& Philippou, G. (2005). Young Pupils' Metacognition Abilities in Mathematics in Relation to Working Memory and Processing Efficiency. European Research in Mathematics. Department of Education, University of Cyprus, Cyprus.

Panaoura, A., Gagatsis, A., \& Demetriou, A. (2009). An intervention to the metacognitive performance: Selfregulation in mathematics and mathematical modeling. Acta Didactica Universitatis Comenianae Mathematics, 9, 63-79.

Purnomo, D., Toto, N., Subanji., dan Swasono, R, (2016). Metacognition process characteristics of the students in solving mathematics problems. IOSR Journal of Research \& Method in Education (IOSRJRME), 6(5), 26-35.

Schraw, G., \& Dennison, R. S. (1994). Assessing metacognitive awareness. Contemporary educational psychology, 19(4), 460-475.

Shanon, S.V. (2008). Using Metacognition Strategies and Learning Styles to Create SelfDirected Learners. Institute for Learning Styles Journal, Volume 1, 1-15. USA : Wayne State College.

Siswono, T. Y. E. (2008). Model pembelajaran matematika berbasis pengajuan dan pemecahan masalah untuk meningkatkan kemampuan berpikir kreatif. Surabaya: Unesa University Press.

Veloo, A., Rani, M. A., \& Hariharan, K.(2015). The Role of Gender in the Use of Metacognitive Awareness Reading Strategies among Biology Students. Asian Social Science, 11(1), 6773. Retrieved from: https://core.ac.uk/download/pdf/78485760.pdf 
